\section{Formulation and shelf-life of fish burgers served to preschool children}

\author{
Giorgio Smaldone, ${ }^{1}$ Raffaele Marrone, ${ }^{1}$ \\ Tiziana Zottola, ${ }^{2}$ Lucia Vollano, \\ Giulio Grossi, ${ }^{1}$ Maria Luisa Cortesi ${ }^{1}$ \\ ${ }^{1}$ Department of Veterinary Medicine and \\ Animal Production, University of Naples \\ Federico II, Naples; ${ }^{2}$ Institute for \\ Experimental Veterinary Medicine of \\ Lazio and Tuscany, Latina, Italy
}

\section{Abstract \\ Consumer is very careful about healthi-} ness; in this context nutritionists often highlight the importance of fish for human nutrition because of their protein and fatty acid composition. In order to stimulate utilisation and consumption of fish species by unusual target groups such as children, the aim of this research was to formulate and to evaluate shelf-life and nutritional values of fish preparations stored in modified atmosphere packaging (MAP). Fish species used for trail were Trachurus trachurus and Oncorhynchus mykiss fished and farmed in Basilicata region respectively. Fish burgers were made with different ingredients of plant and animal origin and packed in air (control) and in MAP and stored at refrigeration atemperature. Sensory, physicalchemical analysis as $\mathrm{pH}, \mathrm{a}_{\mathrm{w}}$, total volatile nitrogen (TVN), trimetilammine (TMA), thiobarbituric acid (TBA), free fatty acids (FFA) and microbiological analysis like aerobic plate count, Enterobacteriaceae, Escherichia coli, Pseudomonas spp., sulphite-reducing clostridia, Staphylococci, Salmonella spp. and Listeria monocytogenes were performed at intervals of $0^{\circ}, 1^{\circ}$, $2^{\circ}, 5^{\circ}, 8^{\circ}, 15^{\circ}, 22^{\circ}$, day from production. Results showed that fish burgers stored in MAP had a longer shelf-life; protein degradation indexes and spoilage bacterial species showed lower values in the samples packaged in MAP compared with the control. The formulation of the fish burger meets the approval of the target consumers. The mixing of natural ingredients has made possible both the enhancement of the organoleptic characteristics with an excellent balance of nutritional values. The diversification of fish preparations, besides enhancing the fish production of marginal areas would add value to a product with potential and remarkable profit margins.

\section{Introduction}

Seafood is an important part of a healthy diet (Altekruse et al., 1995; Trondsen et al., 2003) and nutritionists often highlight the importance of fish for human nutrition because of their protein and fatty acid composition. On the other hand fresh fish could be infested by zoonotic parasites (Cipriani et al., 2015; Giarratana et al., 2015a, 2015b; Anastasio et al., 2016) or could contain traces of environmental contaminants such as PAHs (Marrone et al., 2011, 2012), antibiotics (Smaldone et al., 2014) or other compounds (Mercogliano et al., 2013). Fresh fish is a highly perishable product, given its particular composition, the high water content and the fishing techniques. In this context, it is important to store fish in optimal conditions in order to prolong the shelf-life preserving their nutritional characteristics. Besides the short shelf-life, two important factors represent a barrier to fresh fish consumption: the consideration of seafood product as a timeconsuming meal (Trondsen et al., 2003) and the scarce appeal of fresh fish for children (notoriously not prone to this foods especially in inland areas). A strategic solution to overcome the problem has been to direct the consumer preferences towards fast food consumption. Street foods like fish and chips or fish-based products like fish balls and fish burgers, products with high convenient quality, could increase fish consumption and face off the modern consumer demand (Herborg, 1976; Sipos et al., 1979; Siaw et al., 1985; Ihm et al., 1992a, 1992b; Jensen, 1993; Lazos, 1996; Ariano et al., 2014). At the moment for fish burger production fresh or frozen seafood from freshwater-farmed fish are generally used due to their less pronounced flavour and high fat content. In order to stimulate the utilisation and consumption of fish species by unusual target groups such as children, the aim of this research was to formulate and to evaluate the shelf-life and nutritional values of fish preparations packed in modified atmosphere (MAP).

\section{Materials and Methods}

\section{Fish burger preparation}

Fish species used for the trails were Trachurus trachurus (horse mackerel, HM) and Oncorhynchus mykiss (rainbow trout, RT) fished and farmed in Basilicata region, respectively. After catch the fish were packed in insulated polystyrene boxes with ice and delivered, within $3 \mathrm{~h}$ from harvest, to the Food Chemistry laboratory of the
Correspondence: Raffaele Marrone, Department of Veterinary Medicine and Animal Production, University of Naples Federico II, 80137 Naples, Italy.

Tel: +39.081 .2536464$

E-mail: raffaele.marrone@unina.it

Key words: Fish burgers; Shelf-life; Preschool children.

Conflict of interest: the authors declare no potential conflict of interest.

Received for publication: 8 November 2016. Revision received: 6 February 2017.

Accepted for publication: 7 February 2017.

This work is licensed under a Creative Commons Attribution-NonCommercial 4.0 International License (CC BY-NC 4.0).

(C) Copyright G. Smaldone et al., 2017 Licensee PAGEPress, Italy

Italian Journal of Food Safety 2017; 6:6373 doi:10.4081/ijfs.2017.6373

Department of Veterinary Medicine and Animal Production, University of Naples Federico II. An aliquot was analysed for physical-chemical and microbial parameters and the remaining aliquots were delivered in 2 hours to a food factory for fish burger preparation.

Skin-off fillets of both species were weighed and mixed in order to obtain a fish burger with ratio fish/other ingredients of 60:40 (w/w). In order to obtain a product with balanced composition of micro and macronutrients different ingredients of vegetable and animal origin such as beet, potato, rice, beans, cheese and spices (turmeric and cinnamon, in particular) were added. The fish burgers were prepared manually for a final weight of $40 \pm 5 \mathrm{~g}$, packed in highbarrier plastic bags (Nylon/Polyethylene) and divided in control samples in air (HM$\mathrm{C}$ and RT-C), and MAP samples (HM-MAP and RT-MAP) having the following gas mix composition: 5:60:35 $\mathrm{O}_{2}: \mathrm{CO}_{2}: \mathrm{N}_{2}$. All samples were stored at refrigeration temperature. Fish burgers were prepared without the addition of chemical additives.

\section{Sensory evaluation and panel test}

To evaluate the sensory quality of fish burgers a scheme developed by Paulus et al. (1979) was used. All fish burgers (HM-C, RT-C, HM-MAP and RT-MAP) were cooked on electric grill for 4-5 minutes and served to ten panellists to evaluate the organoleptic characteristics (colour, odour, flavour, spice, texture, overall acceptability). The test evaluation uses a 9-point scale with a score of 7 to 9 for high quality prod- 
ucts, 4 to 6 for middle quality and 1 to 3 for an unacceptable one. A panel test was designed and developed using emoticons that express five emotional states, in order to be easily understood by children aged between 3 and 5 years. The panel test was done by 27 children of a nursery school who did not know the ingredients of fish burgers.

\section{Physical-chemical analyses}

Parameters as $\mathrm{pH}, \mathrm{a}_{\mathrm{w}}$, total volatile basic nitrogen (TVB-N), trimethylamine (TMA), free fatty acids (FFA) and thiobarbituric acid test (TBA) were evaluated. For labelling purposes, according to EU Reg.1169/2011, total fat content, total saturated fat, sugars, carbohydrates, proteins,
$\mathrm{NaCl}$ and energy were determined according to AOAC (2000). All analyses were conducted in duplicate.

\section{Microbiological analyses}

Aerobic plate count (APC) at $5^{\circ}, 20^{\circ}$ and $32^{\circ} \mathrm{C}$; Enterobacteriaceae; E.coli; Pseudomonas spp.; sulphite-reducing clostridia; Staphylococci; Salmonella spp. and Listeria monocytogenes were researched according to the International Commission on Microbiological Specifications for Foods (ICMSF, 1986). During storage at $4{ }^{\circ} \mathrm{C}$ all analyses were performed at day 0 (raw materials), 1, 5, 8, $15,22$.

\section{Results}

\section{Panel test}

Panel test gave similar results for the two different types of fish burgers. Over $85 \%$ of children expressed high appreciation of both fish burger preparations and said they would eat the burgers again.

\section{Sensory evaluation}

The HM-MAP and RT-MAP fish burgers showed good organoleptic characteristics until the $18^{\text {th }}$ day from production, presenting lively and bright colours, good texture, smell and pleasant flavour (Figure 1) and absence of liquid in the package. The
A

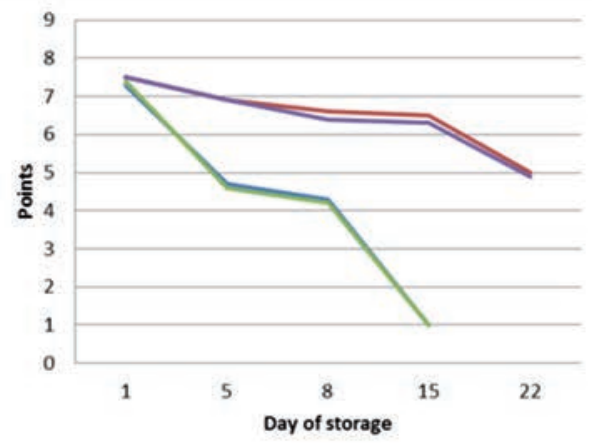

C

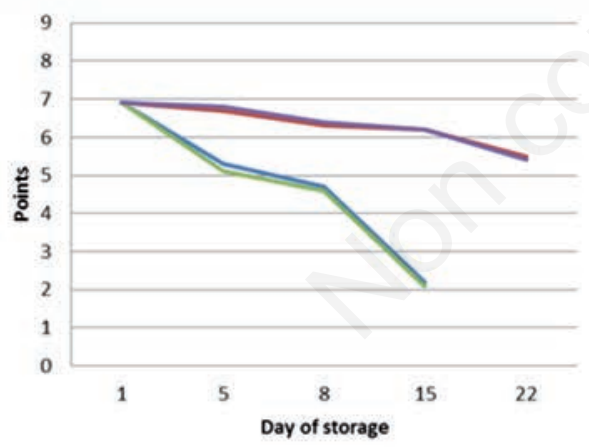

E

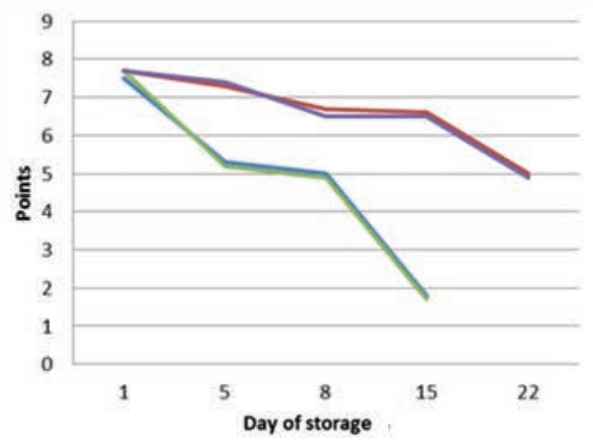

B

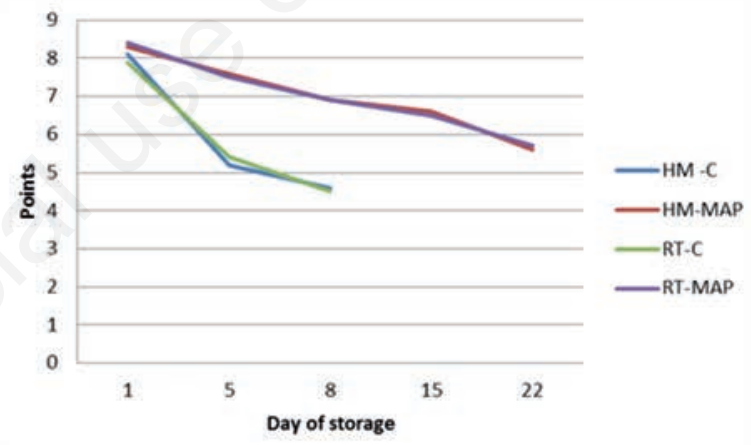

D

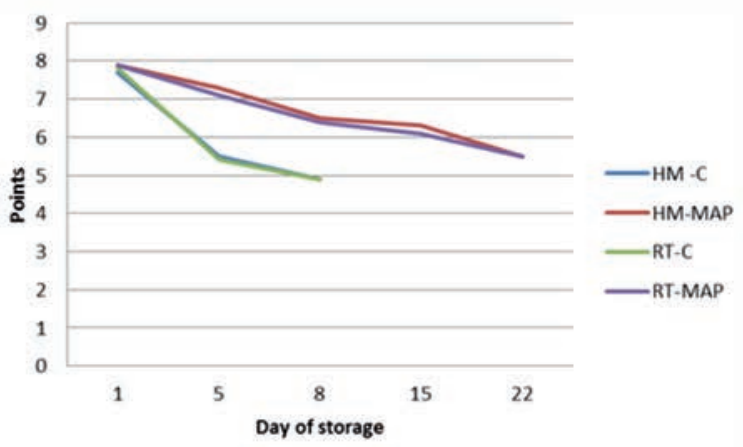

F

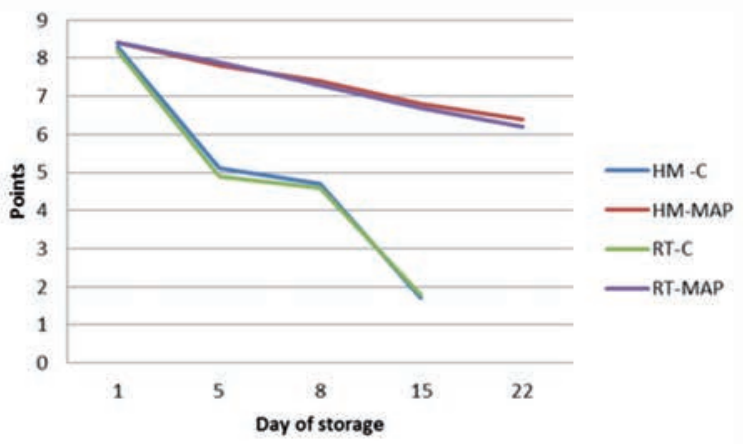

Figure 1. Trend of sensory evaluation: overall acceptability (A), colour (B), texture (C), odour (D), flavour (E), spice (F). 
same preparations exhibited a complete decay of the organoleptic properties on the $20^{\text {th }}$ day given the progressively decreased texture, the smell modifications and the presence of small blackish spots. In the control samples a rapid decline of the sensory parameters were observed from day 5 since they showed an acrid odour and less consistency. Maximum decay occurred on the $12^{\text {th }}$ day.

\section{Physical-chemical analyses}

In HM fish burger $\mathrm{pH}$ levels ranged from values of 6.12 and 6.01 on the $1^{\text {st }}$ day of sampling to a final value of 4.92 on $15^{\text {th }}$ day and 4.94 on $22^{\text {nd }}$ day of storage for the HM-MAP and HM-C, respectively. In RT fish burger $\mathrm{pH}$ levels ranged from values of 6.14 and 5.93 on the $1^{\text {st }}$ day of sampling to a final value of 5.34 on $15^{\text {th }}$ day and 4.97 on $22^{\text {nd }}$ day of storage for the RT-MAP and RT$\mathrm{C}$, respectively. Both types of fish burger showed similar behaviour with a reduction of the $\mathrm{pH}$ value starting from $8^{\text {th }}$ day of storage.

Levels of $\mathrm{a}_{\mathrm{w}}$ of the HM-C and RT-C ranged from 0.983 and 0.9816 to a final value of 0.9803 and 0.9753 , respectively. Fish burger packaged in modified atmosphere showed a different behaviour. In fact $a_{w}$ was constant until the $5^{\text {th }}$ day of storage, then raised up to $15^{\text {th }}$ day, probably due to condensation inside the package.

TBA test showed a similar behaviour in both types of samples with an increase from the $2^{\text {nd }}$ day of storage reaching the peak on the $5^{\text {th }}$ day of storage. Then a steady decrease was observed until the end of the experimentation. Starting from the $5^{\text {th }}$ day, the values of control samples were lower than those MAP samples; however, no samples exceeded the maximum limit of 2 $\mathrm{mg} / \mathrm{kg}$ of malonaldehyde reported in literature (Connell, 1990).

Regarding the FFA, the oleic acid percentage in control samples were constant up to the $8^{\text {th }}$ day of storage and showed a sudden increase on the $15^{\text {th }}$ day. On the contrary, the values of the MAP fish burgers remained constant throughout the experimental period.

TVB-N levels of raw material start from $9.18 \mathrm{mg} / 100 \mathrm{~g}$ and $8.81 \mathrm{mg} / 100 \mathrm{~g}$ in HM and RT fish burgers, respectively, whereas the TMA was undetectable (Figure 2). These analyses showed the same behaviour in the four types of samples with superimposable values until the $5^{\text {th }}$ day. An increase in samples from the $8^{\text {th }}$ day $(>30 \mathrm{mg} / 100 \mathrm{~g}$ for the TVB-N and $>15 \mathrm{mg} 100 \mathrm{~g}$ for TMA in HM fish burgers) up to 15 day and 22 day was observed in control and treated samples, respectively.

\section{Microbiological analyses}

The initial APC in HM resulted high, probably due to the time elapsed from the capture to manipulation. In RT samples, the initial level of APC appeared slightly lower showing values of $5.1 \log _{10} \mathrm{CFU} / \mathrm{g}$. During storage a progressive increase in the APC, more pronounced in control samples than in MAP samples, was noted and in the third sampling interval the levels were $9.33 \log _{10}$ $\mathrm{CFU} / \mathrm{g}$ and $7.63 \log _{10} \mathrm{CFU} / \mathrm{g}$ in the HM-C and HM-MAP and $9.23 \log _{10} \mathrm{CFU} / \mathrm{g}$ and $7.13 \log _{10} \mathrm{CFU} / \mathrm{g}$ in the RT-C and RT-MAP, respectively.

Enterobacteriaceae showed a trend comparable to the APC reaching on the $8^{\text {th }}$ day values of $7.89 \log _{10} \mathrm{CFU} / \mathrm{g}$ (HM-C) and $6.29 \log _{10} \mathrm{CFU} / \mathrm{g}$ (RT-C). These levels were observed in HM-MAP on the $15^{\text {th }}$ day but never in the RT-MAP.

Pseudomonas spp. was found always during the storage period: at a concentration of $8.1 \log _{10}$ CFU/g in the HM-C and RT-C on the $8^{\text {th }}$ day, while in both MAP fish burgers this microorganism reached a maximum level of $4.1 \log _{10} \mathrm{CFU} / \mathrm{g}$ (Figure 3).

With the increase in the number of the APC and Pseudomonas spp. a progressive decay of organoleptic characteristics was observed.

Sulphite-reducing clostridia, potentially pathogenic Staphylococci and Salmonella spp. were never isolated.

L. monocytogenes was constantly isolated both in raw material and in fish burgers during the whole sampling period: in particular on the $15^{\text {th }}$ day $L$. monocytogenes reached $5 \log _{10} \mathrm{CFU} / \mathrm{g}$ and $4 \log _{10} \mathrm{CFU} / \mathrm{g}$ in HM-C and HM-MAP and $2 \log _{10} \mathrm{CFU} / \mathrm{g}$ and $<2 \log _{10} \mathrm{CFU} / \mathrm{g}$ in RT-C and RT-MAP, respectively. The strains were all classified as serotype $1 / 2 \mathrm{~b}$.

\section{Nutritional value}

Table 1 shows the nutritional value of fish burgers. As regards the energy value, HM fish burgers developed $178.5 \mathrm{kcal} / 100$ $\mathrm{g}$ of product, less than RT samples (185 $\mathrm{kcal} / 100 \mathrm{~g}$ of product). Fish burgers showed to be low fat preparations $(8.8 \mathrm{~g} / 100 \mathrm{~g}$ for $\mathrm{HM}$ and $7.5 \mathrm{~g} / 100 \mathrm{~g}$ for RT) with a good protein content $(14.5 \mathrm{~g} / 100 \mathrm{~g}$ for HM and $15.3 \mathrm{~g} / 100 \mathrm{~g}$ for RT). Purely structural carbohydrates were present due to the presence of rice, legumes and potatoes. The percentages of saturated fatty acids showed very low values (higher in RT fish burgers). The sodium content resulted $<1 \%$ in both types of fish burgers.

\section{Discussion}

The formulation of the fish burgers met the approval of the target consumers. The mixing of natural ingredients (vegetable and animal origin products) made possible both the enhancement of the organoleptic characteristics and the proposition of a meal ( 2 fish burgers for a total of $80 \mathrm{~g}$ per capita) with an excellent balance of nutritional values suitable for children needs during the growth age, with micro and macro elements, in balanced proportions, and a low calorie intake.

Results showed that from the sensory point of view, fish burgers stored with MAP had a longer shelf-life due to retained appearance and unchanged colour until the $18^{\text {th }}$ day of storage. These findings are supported by the protein degradation indexes and spoilage bacterial species that showed lower values in the samples packaged in MAP compared with the control.

It should however be emphasised that even if the organoleptic characteristics make the MAP samples marketable up to the $18^{\text {th }}$ day and control samples up to the $12^{\text {th }}$ day, considering the high levels of TVB-N, TMA and the bacterial counts, the shelf-life should be reduced in our opinion to 8 days for the control and to 15 days for packaged samples. This shelf-life should allow food business operators to plan the supplies once a week.

As far as microbiological analyses are concerned no limits are established for APC for this type of product. The International Commission of Microbiological Standards for Foods (ICMSF, 1978) proposed a maximum level of $7 \log _{10} \mathrm{CFU} / \mathrm{g}$ of APC for the acceptance of certain fish preparations (steaks, fillets, etc.). Taking into account these levels, control samples would no longer be marketable from the $8^{\text {th }}$ day whereas MAP fish burgers exceeded this

Table 1. Nutritional value of fish burgers.

\begin{tabular}{lcc} 
Average values per $\mathbf{1 0 0} \mathrm{g}$ & HM & RT \\
Calories (kcal) & 178.5 & 185 \\
Proteins (g) & 14.5 & 15.3 \\
\hline Carbohydrates (g) & 12.5 & 15 \\
Sugars (g) & 3.7 & 4.1 \\
\hline Fat (g) & 8.8 & 7.5 \\
Saturated fat (g) & 0.5 & 2.1 \\
\hline Sodium (g) & 0.9 & 0.52 \\
\hline
\end{tabular}

HM, horse mackerel; RT, rainbow trout. 
limit only in the last sampling interval. Pseudomonas spp., which together with Aeromonas spp. belongs to the microflora defined by Gram and Dalgaard (2002) as specific spoilage organisms of fresh and processed fishery products, should be considered the main bacterial microrganisms responsible for the off flavour of these products when the number exceeds the value of the $7 \log _{10}$ CFU/g. (Giuffrida et al., 2007). The isolation of L. monocytogenes deserves a particular consideration. There is evidence that not all L. monocytogenes strains are pathogenic or present the same level of virulence. Only few $(1 / 2 a, 1 / 2 b$, and $4 b)$ of the thirteen L. monocytogenes serotypes appear to be most frequently involved in foodborne outbreaks (EFSA, 2007). The isolated serotype is one of the most pathogenic agent of invasive listeriosis (EFSA, 2007); Parameters associated with the presence of the bacterium include food packaging type, preparation practices (e.g. the use of slicing machines for meat products), storage temperatures, the stage of sampling with respect to shelf-life, the lack of an effective HACCP system and the lack of education

A

B
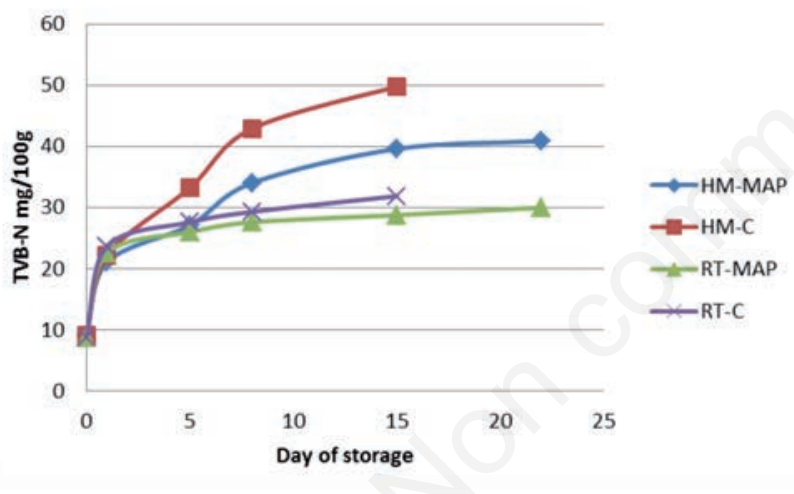
$\longrightarrow$ RT-C
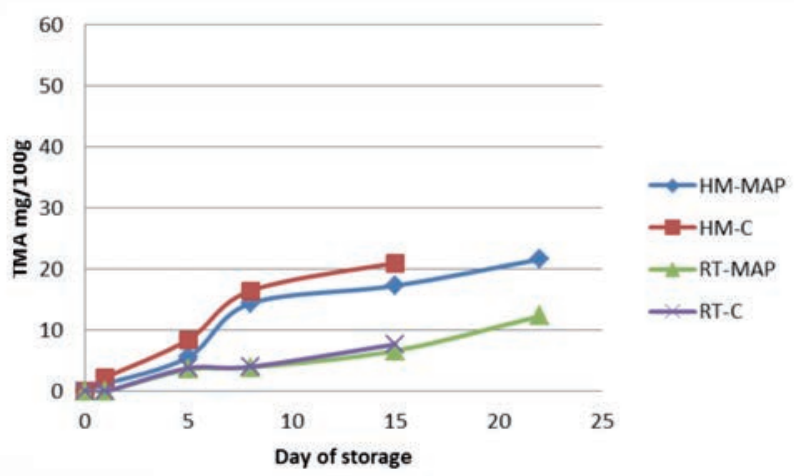

-RT-MAP

$\longrightarrow$ RT-C

Figure 2. Physical-chemical analyses in fish burgers: trend of total volatile basic nitrogen $(A)$ and trimethylamine $(B)$. can allow the growth of the pathogen during storage. However L. monocytogenes was not isolated from the swabs on the tools used for mixing the different ingredients in the factory where fish burgers were prepared.

\section{Conclusions}

The possibility to diversify methods of presentation and preparation using raw material of excellent quality could be an interesting enhancement tool of the socalled poor fish. Hospital or school canteen could insert this kind of product in their menu in order to sensitise children to fish consumption. Moreover, by diversifying the production of this kind of fresh foods, the
A

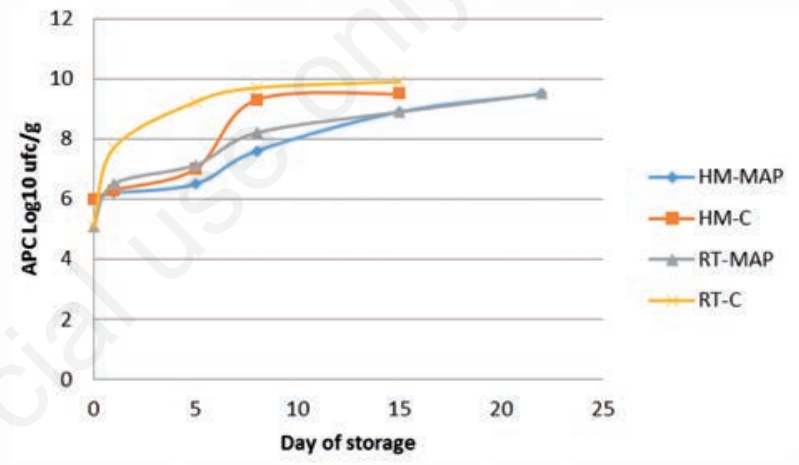

B

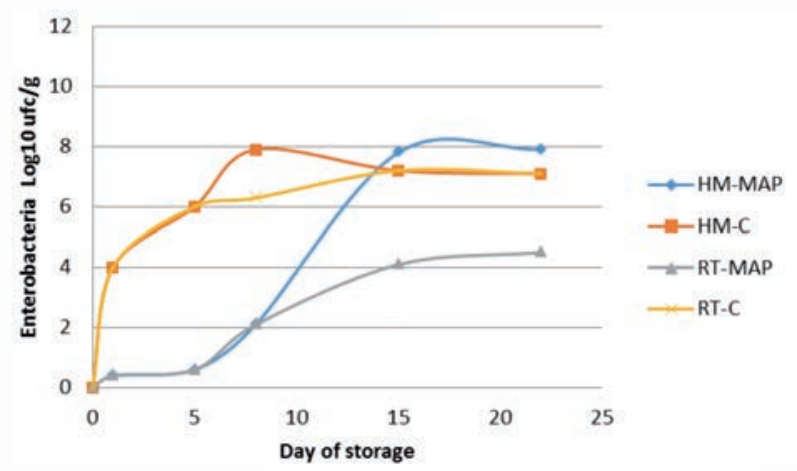

C

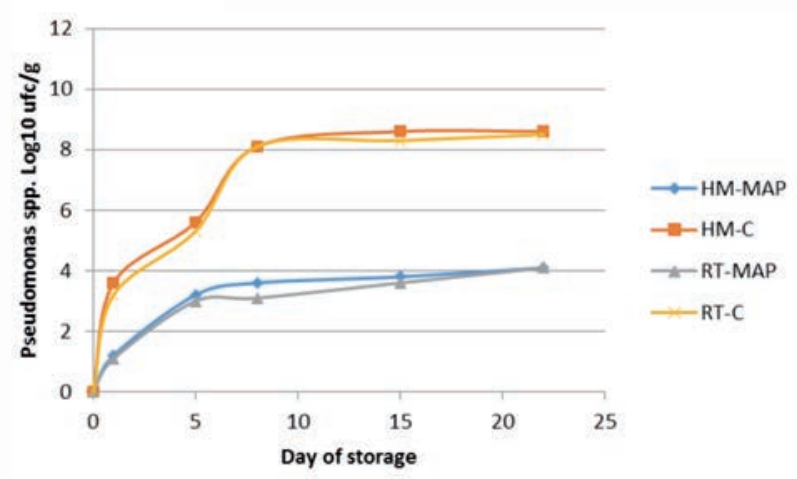

Figure 3. Microbiological analyses in fish burgers: trend of aerobic plate count (A), Enterobacteria (B), and Pseudomonas spp. (C). 
fish production of marginal areas might give added value to a product with potential and remarkable profit margins.

\section{References}

Altekruse SF, Timbo BB, Headdrick ML, Klontz KC, 1995. Associations between diet and health behavior: results from the 1992 Rhode Island Behavior Risk Factor Survey. J Behav Med 18:225-32.

Anastasio A, Smaldone G, Cacace D, Marrone R, Lo Voi A, Santoro M, Cringoli G, Pozio E, 2016. Inactivation of Anisakis pegreffii larvae in anchovies (Engraulis encrasicolus) by salting and quality assessment of finished product. Food Control 64:115-9.

AOAC, 2000. Official methods of analysis, $17^{\text {th }}$ edition. Association of Official Analytical Chemists, Gaithersburg, MD, USA.

Ariano A, Scarano L, Mormile A, Barile M, Palma G, Murru N, 2014. Shelf-life of anchovy products (Engraulis encrasicolus): evaluation of sensory, microbiological and chemical properties. Ital J Food Safety 3:1678.

Cipriani P, Smaldone G, Acerra V, D'Angelo L, Anastasio A, Bellisario B, Palma G, Nascetti G, Mattiucci S, 2015. Genetic identification and distribution of the parasitic larvae of Anisakis pegreffii and Anisakis simplex (s.s.) in European hake Merluccius merluccius from the Tyrrhenian Sea and Spanish Atlantic coast: implications for food safety. Int J Food Microbiol 198:1-8.

Connell JJ, 1990. Methods of assessing and selecting for quality. In: J.J. Connell (ed.) Control of fish quality (3rd ed). John Wiley \& Sons, Inc., New York, NY, USA, pp 122-50.

EFSA, 2007. Scientific opinion of the panel on biological hazards on a request from the European Commission for updating the former SCVPH opinion on Listeria monocytogenes risk related to ready-toeat foods and scientific advice on different levels of Listeria monocytogenes in ready-to-eat foods and the related risk for human illness. EFSA J 599:1-42.

Giarratana F, Muscolino D, Panebianco F, Patania A, Benianti C, Ziino G, Giuffrida A, 2015a. Activity of $\mathrm{R}(+)$ limonene against anisakis larvae. Ital J
Food Safety 4:5499.

Giarratana F, Panebianco F, Muscolino D, Beninati C, Ziino G, Giuffrida A, 2015b. Effect of allyl isothiocyanate against Anisakis larvae during the anchovy marinating process. J Food Protect 78:767-71.

Giuffrida A, Ziino G, Valenti D, Donato G, Panebianco A, 2007. Application of an interspecific competition model to predict the growth of Aeromonas hydrophila on fish surfaces during refrigerated storage. Arch Lebensmittelhyg 58:13641.

Gram L, Dalgaard P, 2002. Fish spoilage bacteria: problems and solutions. Curr Opin Biotechnol 13:262-6.

Herborg L, 1976. Production of separated fish mince for traditional and new products. Food Minced Fish Symp 1:82-3.

ICMSF, 1978. Microorganisms in foods (Vol. 2). The International Commission on Microbiological Specifications for Foods, Toronto, Canada.

ICMSF, 1986. Sampling plans for fish and shellfish. Microorganisms in foods 2 . Sampling for microbiological analysis: principles and scientific applications, 2nd edition. University of Toronto Press, Toronto, Canada.

ICSMF, 1996. Microorganisms in foods (Vol. 5). Characteristics of microbial pathogens. International Commission on Microbiological Specifications for Foods, Blackie Academic \& Professional, London, UK.

Ihm CW, Kim JS, Joo DS, Lee HE, 1992a. Processing and quality stability of precooked frozen fish foods. Part I: processing of sardine burger. J Korean Agric Chem Soc 35:254-9.

Ihm CW, Kim JS, Joo DS, Lee HE, 1992b. Processing and quality stability of precooked frozen fish foods. Part II: processing of sardine burger. J Korean Agric Chem Soc 35:260-4.

Jensen J, 1993. Fancy fish products. Food Marketing Technol 1993:6-8.

Lazos SE, 1996. Utilization of freshwater bream for canned fish ball manufacture. J Aquat Food Prod Technol 5:47-64.

Lewis HC, Little CL, Elson R, Greenwood M, Grant KA, McLauchlin J, 2006. Prevalence of Listeria monocytogenes and other Listeria species in butter from United Kingdom production, retail, and catering premises. J Food Protect 69:1518-26.
Lianou A, Sofos JN, 2007. A review of the incidence and transmission of Listeria monocytogenes in ready-to-eat products in retail and food service environments. J Food Protect 70:2172-98.

Marrone R, Mercogliano R, Palma G, Chirollo C, Smaldone G, Anastasio A, 2011. Polycyclic aromatic hydrocarbons (PAHs) in seafood caught off in Napoli gulf (Italy). Ital J Food Safety $1: 61$.

Marrone R, Smaldone G, Pepe T, Mercogliano R, De Felice A, Anastasio A, 2012. Polycyclic aromatic hydrocarbons (PAHs) in seafood caught in Corigliano Calabro gulf (CS, Italy). Ital J Food Safety 1:41-6.

Mercogliano R, De Felice A, Cortesi ML, Murru N, Marrone R, Anastasio A, 2013. Biogenic amines profile in processed bluefin tuna (Thunnus thynnus) products. CYTA J Food 11:101-7.

Paulus K, Zacharias R, Robinson L, Geidel H, 1979. Kritische Betrachtungen zur "Bewertenden Prüfung mit Skale" als Einem Wesentlichen Verfahren der Sensorichen Analyse. Lebensm Wiss Technicol 12:52-61.

Sagoo SK, Little CL, Allen G, Williamson K, Grant KA, 2007. Microbiological safety of retail vacuum-packed and modified-atmosphere-packed cooked meats at end of shelf-life. J Food Protect 70:943-51.

Siaw CL, Idrus AZ, Yu Y, 1985. Intermediate technology for fish craker (keropok) production. J Food Technol 20:17-21.

Sipos EF, Endres JG, Tybor PT, Nakajima $\mathrm{Y}, 1979$. Use of vegetable protein in processed seafood products. J Am Oil Chemists Soc 56:320-7.

Smaldone G, Marrone R, Cappiello S, Martin GA, Oliva G, Cortesi ML, Anastasio A, 2014. Occurrence of antibiotic resistance in bacteria isolated from seawater organisms caught in Campania Region: preliminary study. BMC Vet Res 10:161.

Trondsen T, Scholderer J, Lund E, Eggen AE, 2003. Perceived barriers to consumption of fish among Norwegian women. Appetite 41:301-14. 